\title{
Duodenal Villous Adenoma
}

National Cancer Institute

\section{Source}

National Cancer Institute. Duodenal Villous Adenoma. NCI Thesaurus. Code C5338.

A neoplasm that arises from the glandular epithelium of the duodenum. It is

characterized by a villous architectural pattern. The neoplastic glandular cells have dysplastic features. 